Research Article

\title{
A clinical study of head and neck malignancy in a tertiary hospital
}

Hamsa Shetty*, Gangadhar K. S.

Department of ENT, Shimoga Institute of Medical Sciences, Shimoga, Karnataka, India

Received: 27 August 2015

Accepted: 02 October 2015

\author{
*Correspondence: \\ Dr. Hamsa Shetty, \\ E-mail: hamsa.shetty@rediffmail.com
}

Copyright: (C) the author(s), publisher and licensee Medip Academy. This is an open-access article distributed under the terms of the Creative Commons Attribution Non-Commercial License, which permits unrestricted non-commercial use, distribution, and reproduction in any medium, provided the original work is properly cited.

\begin{abstract}
Background: Head and Neck Malignancy (HNM) is a recognized major public health concern all over the world. They are amongst the commonest malignancy in India and accounts for up to $20 \%$ cancer burden in India.

Methods: Ours is a retrospective study done over 5 years period in a tertiary hospital to study the incidence of head and neck malignancy, age and sex predilection, type of malignancy, its stage of presentation and patient compliance for treatment (surgery/radiotherapy/chemotherapy), post-operative complications, its management and follow-up study of patients survival with or without recurrence over the next 5 years.

Results: Total of 312 cases of HNM were seen in ENT OPD in tertiary hospital over a period of 5 years. In 153 cases diagnosis was confirmed by biopsy/histopathology, only 15 patients agreed for surgery. Hypopharyngeal and laryngeal malignancy accounted for most of the cases. Mean age of patients - in case of laryngeal ca was 56.8, hypopharyngeal ca was 60 . Majority were males.

Conclusions: Despite having a large turnover of HNM patients only 15 patients were willing to undergo curative surgery. This less number could be due to unwillingness to accept deformity, patient's low economic status, lack of awareness amongst both patients and referring doctors, and lastly either due to advanced stage of disease or patient being medically unfit for surgery. However in our study 14 out of 15 patients who underwent curative surgery had more than 5 years survival rate with very few post-operative complications.
\end{abstract}

Keywords: Carcinoma, Laryngectomy, Pharyngocutaneous fistula, Recurrence

\section{INTRODUCTION}

Head and Neck Malignancy (HNM) is a recognized major public health concern all over the world. ${ }^{1}$ They are amongst the commonest malignancy in India and accounts for up to $20 \%$ cancer burden in India. ${ }^{2}$

Head and Neck Cancer (HNC) cases are a major health concern as it is growing at an alarming rate. ${ }^{3}$ In India $25 \%$ of all male cancers and $10 \%$ of female cancers are reported to be head and neck cancers. ${ }^{4}$ HNC cases among Indian females are highest in the world. ${ }^{5}$ By the year $202019 \%$ of all cancers are expected to be HNC. ${ }^{6} 57.5 \%$ of global HNC do occur in Asia, ${ }^{6}$ specially in India. 60-
$80 \%$ cases in India are diagnosed with later stages of cancer reducing the survival rate. ${ }^{7}$

In our study, retrospectively patients with head and neck malignancy were studied over 5 years period who visited the ENT OPD in a tertiary care hospital. Our main focus is to study the incidence of head and neck malignancy, age and sex predilection, type of malignancy, its stage of presentation and patient compliance for treatment (surgery/radiotherapy/chemotherapy). Post-operative complications, its management and follow-up study of patients survival with or without recurrence over the next 5 years. 


\section{METHODS}

Retrospective study of patient with head and neck malignancy presenting to the ENT OPD over a period of 5 years in a tertiary care hospital. Total number of patients who were clinically diagnosed as head and neck malignancy were recorded. Number of patients who underwent biopsy/HPE were recorded. Male female ratio was assessed, age incidence determined. No. of patients who complied with the suggested modality of treatment were recorded. Post-operative complications tabulated along with its management and recurrence rate and follow-up of patients with/without recurrence at 5 years was recorded.

\section{RESULTS}

A total of 312 cases were diagnosed clinically with head and neck malignancy, 153 cases underwent biopsy and were confirmed by HPE. Hypopharyngeal and laryngeal malignancy accounted for most of the cases. Mean age of patients - in case of laryngeal ca was 56.8, hypopharyngeal ca was 60 . Majority were males. All the 8 patients of hypopharyngeal and laryngeal malignancy who underwent total laryngectomy with or without partial pharyngectomy with or without radical neck dissection were all males.

Table 1: Site predilection.

\begin{tabular}{|l|l|}
\hline Site & No. \\
\hline Face & 5 \\
\hline Oral cavity & 32 \\
\hline Nasopharynx & 9 \\
\hline Oropharynx & 45 \\
\hline Hypopharynx & 96 \\
\hline Larynx & 74 \\
\hline Nose \& PNS & 7 \\
\hline Oropharynx & 38 \\
\hline Parapharyngeal space & 2 \\
\hline Bronchus & 4 \\
\hline Total & 312 \\
\hline
\end{tabular}

Table 2: Number of patients who underwent biopsy and malignancy was confirmed.

\begin{tabular}{|l|l|}
\hline Site & No. \\
\hline Face & 5 \\
\hline Oral cavity & 14 \\
\hline Nasopharynx & 4 \\
\hline Oropharynx & 22 \\
\hline Hypopharynx & 47 \\
\hline Lanryx & 36 \\
\hline Nose and PNS & 4 \\
\hline Oesophagus & 18 \\
\hline Parapharyngeal space & 1 \\
\hline Bronchus & 2 \\
\hline Total & 153 \\
\hline
\end{tabular}

Out of the 5 malignant cases of face, 1 case was of squamous cell carcinoma in xeroderma pigmentosa. This case was not operated as lesion was extensive. 2 cases were of Basal Cell Carcinoma (BCC) (Figure 1, 2, 3) and 1 each of Squamous Cell Carcinoma (SCC) and adenocarcinoma of sebaceous gland. In all the four cases, lesion was excised and defect closed with appropriate flaps (Table 3).

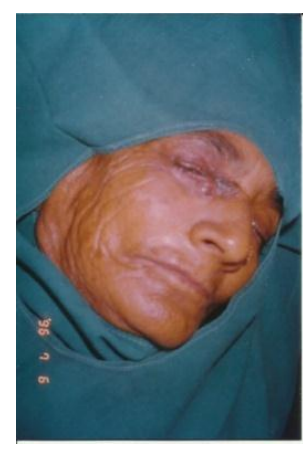

Figure 1: Basal cell carcinoma.

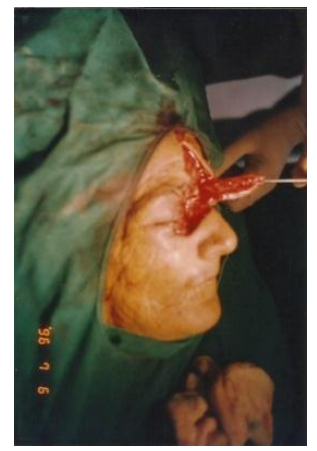

Figure 2: Basal cell carcinoma excision.

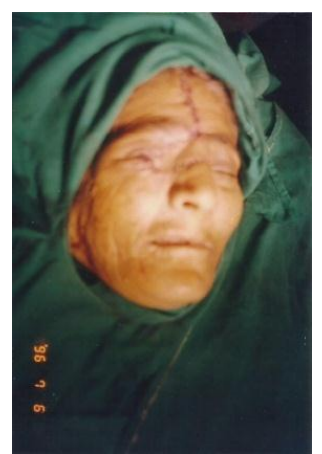

Figure 3: Closure after excision by glabellar fore head flap.

Table 3: Types of malignancy on face; Site: face - 5 cases.

\begin{tabular}{|ll|}
\hline No. & Type \\
\hline 1 & SCC in xeroderma pigmentosa \\
\hline 2 & BCC \\
\hline 1 & SCC \\
\hline 1 & Adeno carcinoma - Sebaceous gland \\
\hline
\end{tabular}


Out of the 14 cases of oral cavity lesion 5 were in stage I, 3 in stage II, 4 in stage III, and 2 in stage IV. Surgery was advised in 6 but none of the patients agreed to undergo the surgery. 2 patients were referred for radiotherapy (RT). 4 were medically unfit for surgery and two had advanced disease (Table 4 ).

Table 4: Staging and management of oral cavity carcinoma; Site: oral cavity - 14 cases.

\begin{tabular}{|lll|}
\hline Stage & No. & Management \\
\hline I & 5 & Surgery advised - 6 \\
\hline II & 3 & RT - 2 \\
\hline III & 4 & Unfit - 4 \\
\hline IV & 2 & Advanced disease - 2 \\
\hline
\end{tabular}

None agreed to undergo the surgery.

Out of 4 nasopharyngeal carcinoma 3 were young (18-27 years) and 1 was 45 years old. All were referred for radiotherapy.

Site: Nasopharynx - 4 cases

Table 5: Age wise distribution of nasopharyngeal carcinoma.

\begin{tabular}{|ll|}
\hline No. & Age \\
\hline 3 & $18-27$ years \\
\hline 1 & 45 years \\
\hline
\end{tabular}

All cases referred to radiotherapy (RT)

Out of the 22 cases of oropharyngeal malignancy 2 were lymphoma tonsil - which were referred for chemotherapy (CT).

Surgery was advised for 4. Only one patient agreed to undergo the surgery. The case was of SCC of soft palate, wide excision followed by defect closure by release incision was done.

Site: Oropharynx - 22 cases

Table 6: Staging and management of oropharyngeal carcinoma. ( 2 cases of lymphoma tonsil - referred for CT). Staging of the remaining 20 cases.

\begin{tabular}{|llll|}
\hline Stage & No. & Management & \\
I & 2 & Surgery advised & $\begin{array}{l}4 \\
\text { (only one underwent } \\
\text { surgery) }\end{array}$ \\
\hline II & 6 & RT & 9 \\
\hline III & 6 & CT & 2 \\
\hline IV & 6 & Unfit & 3 \\
\hline
\end{tabular}

Out of the 47 cases of hypopharyngeal malignancy surgery was advised for 22 patients of which only 4 agreed for surgery. 4 Total Laryngectomy (TL) with
Partial Pharyngectomy (PP) was done. Out of 36 laryngeal malignancy 16 patients were fit of undergoing surgery (TL). Only 4 patients agreed for the same (Figure $4,5,6 \& 7)$.

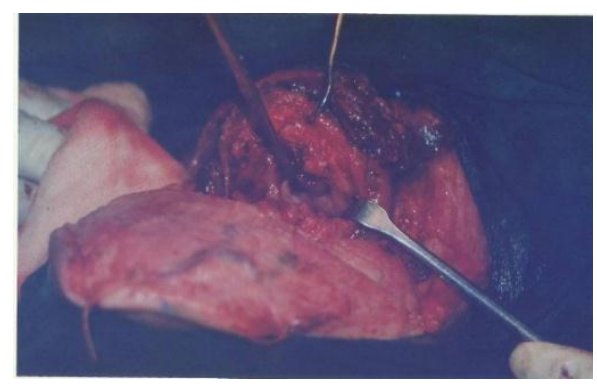

Figure 4: Opening hypopharynx.

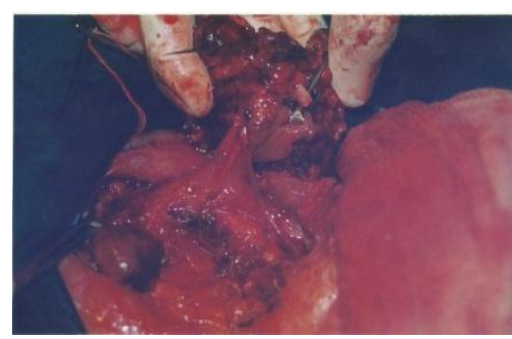

Figure 5: Larynx delivered out.



Figure 6: Total laryngectomy with radical neck dissection.

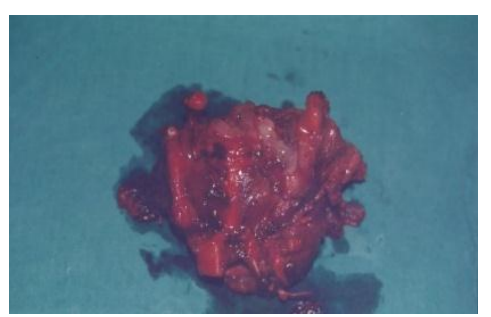

Figure 7: Total laryngectomy - specimen.

Overall 8 TL were done. Out of the 8,3 patients underwent TL with PP, one TL with PP with ipsilateral RND, one TL with ipsillateral RND and remaining 3 underwent TL alone.

Post operatively all 8 patients were referred for RT. 6 completed RT, 1 discontinued due to development of pharyngocutaneous fistula during the course of RT. 
(Figure 10) 1 patient refused to take RT developed recurrence after two years and died a year later. All patients received speech rehabilitation and 5 successfully developed oesophageal speech (Table 7, Table 8, Table 9 and Table 10) (Figure $8 \& 9$ ).

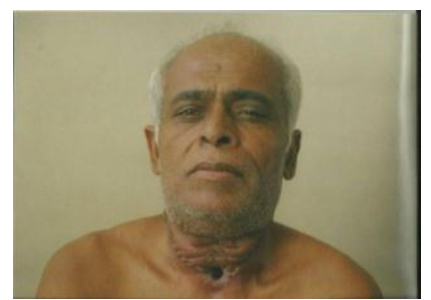

Figure 8: Total laryngectomy - post operative patient.

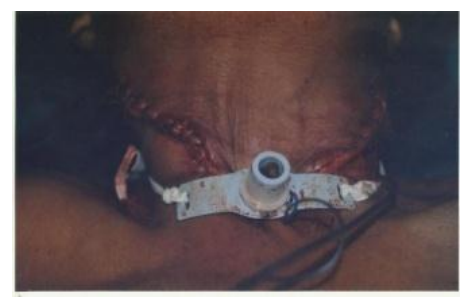

Figure 9: Post total laryngectomy - with tracheostomy tube.

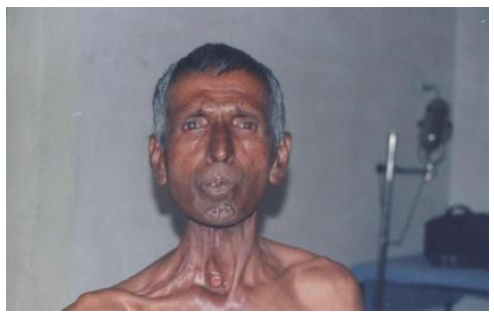

Figure 10: Post total laryngectomy - patient developed pharngocutanuous fistula during $\mathrm{RT}$.

Table 7: Staging and management of laryngeal carcinoma cases; Site: larynx - 36 cases.

\begin{tabular}{|llll|}
\hline Stage & No. & Management & \\
\hline I & 6 & Surgery advised & $\begin{array}{l}16 \\
(4 \text { underwent surgery) }\end{array}$ \\
\hline II & 2 & RT & 8 \\
\hline III & 20 & Unfit & 8 \\
\hline IV & 8 & Advanced disease & 4 \\
\hline
\end{tabular}

Table 8: Staging and management of hypopharyngeal ca cases; Site: hypopharynx - 47 .

\begin{tabular}{|llll|}
\hline Stage & No. & Management & \\
\hline I & 3 & Surgery advised & $\begin{array}{l}22 \\
(4 \text { underwent surgery })\end{array}$ \\
\hline II & 3 & RT & 9 \\
\hline III & 19 & Unfit & 10 \\
\hline IV & 22 & Advanced disease & 6 \\
\hline
\end{tabular}

Table 9: Site and stage wise distribution of laryngeal ca cases and management.

\begin{tabular}{|lll|}
$\begin{array}{l}\text { No. of } \\
\text { cases }\end{array}$ & Site/Stage & Surgery \\
\hline \multirow{2}{*}{3} & $\begin{array}{l}1 \text { - Supraglottis } \\
\text { Stage - III } \\
2-\text { Glottis } \\
\text { Stage - III }\end{array}$ & TL \\
& Stage - IV $-\mathrm{T}_{3} \mathrm{~N}_{1} \mathrm{M}_{0}$ & TL with ipsilateral RND \\
\hline 1
\end{tabular}

Table 10: Histopathological diagnosis of laryngeal ca.

\begin{tabular}{|ll|}
\hline HPE & $\begin{array}{l}\text { No. of } \\
\text { cases }\end{array}$ \\
\hline Well differentiated SCC & 1 \\
\hline Moderately differentiated SCC & 6 \\
\hline Poorly differentiated SCC & 1 \\
\hline
\end{tabular}

Post-operative complications

1. Two patients developed pharngocutaneous fistula - 1 healed by conservative method another patient developed it during radiotherapy and he lived with it with no recurrence at five years follow up.

2. One case developed stomal stenosis - widening / freshening of the edges was done, tracheostomy tube was put and advised to continue using the same.

3. One case developed thyroid and parathyroid deficiency - supplemented.

4. Two patients developed facial adema following RND which subsided in due course.

5. Only one patient died due to recurrence after three years of surgery.

Out of 4 nose and paranasal sinus (PNS) cases one case had extensive disease and was unfit for surgery.

Three cases underwent total maxillectomy followed by radiotherapy (Table $11 \& 12$ ).

Site: Nose and PNS - 4 cases

Table 11: Management of maxillary ca cases.

\begin{tabular}{|ll|}
\hline No. & Management \\
\hline 1 & Extensive and unfit surgery \\
\hline 3 & Total Maxillectomy and post-op RT \\
\hline
\end{tabular}

18 oesophageal, one parapharyngeal space and two carcinoma bronchus were evaluated and sent for RT and CT appropriately. 
Table 12: Age and site distribution of ca maxilla cases with staging; 3 patients who underwent total maxillectomy and radiotherapy.

\begin{tabular}{|lll|}
\hline Age & TNM & Site \\
\hline 50 & $\mathrm{~T}_{3} \mathrm{~N}_{0} \mathrm{M}_{0}$ & Posterior wall of right Maxilla \\
\hline 45 & $\mathrm{~T}_{4} \mathrm{~N}_{0} \mathrm{M}_{0}$ & $\begin{array}{l}\text { Right maxilla extending to } \\
\text { pterygomaxillary fossa }\end{array}$ \\
\hline 48 & $\mathrm{~T}_{4} \mathrm{~N}_{0} \mathrm{M}_{0}$ & $\begin{array}{l}\text { Right maxilla extending till } \\
\text { nasopharynx }\end{array}$ \\
\hline
\end{tabular}

\section{DISCUSSION}

Most head and neck cancers are of epithelial origin. In the literature, it is reported that $75 \%-78 \%$ of head and neck carcinoma are SCC. ${ }^{8,9}$ Which is similar to the findings in our study. Though in our study a large number of cases (Total of 312) of head and neck malignancy were detected in the outpatient department, only 153 patients agreed to undergo biopsy and a total of 55 patients were considered fit for surgery. However only a small number, 15 patients, agreed to undergo curative surgery in our series.

Table 13: Distribution of head and neck malignancy cases.

\begin{tabular}{|lllll|}
\hline Site & $\begin{array}{l}\text { Out } \\
\text { patient }\end{array}$ & Inpatient & $\begin{array}{l}\text { Surgery } \\
\text { advised }\end{array}$ & $\begin{array}{l}\text { Curative } \\
\text { surgery } \\
\text { done }\end{array}$ \\
\hline Face & 5 & 5 & 4 & 4 \\
\hline Oral cavity & 32 & 14 & 6 & 0 \\
\hline Nasopharynx & 9 & 4 & 0 & 0 \\
\hline Orapharynx & 45 & 22 & 4 & 1 \\
\hline Hypopharynx & 96 & 47 & 22 & 4 \\
\hline Larynx & 74 & 36 & 16 & 4 \\
\hline Nose and PNS & 7 & 4 & 3 & 3 \\
\hline Oesophagus & 38 & 18 & 0 & 0 \\
\hline $\begin{array}{l}\text { Parapharyngeal } \\
\text { space }\end{array}$ & 2 & 1 & 0 & 0 \\
\hline Bronchus & 4 & 2 & 0 & 0 \\
\hline
\end{tabular}

Table 14: Overview of the total 312 cases of head and neck malignancy cases.

\begin{tabular}{|ll|}
\hline Cases & No. \\
\hline Seen & 312 \\
\hline Evaluated & 153 \\
\hline Operable & 55 \\
\hline Operated & 15 \\
\hline
\end{tabular}

The reason for low turnover for curative surgery could be low socioeconomic status, ignorance about the need for early evaluation or unwillingness to accept deformity post operatively. Majority of the cases of HNM were males and out of 15 cases who underwent surgery 13 were males. The higher male incidence could be due to almost exclusive use of alcohol, tobacco by males especially gutka, panmasala. Though beedi smoking, betel quid and arecanut chewing is practiced among rural females, to a lesser extent compared to males. This could also be due to prevailing local socio cultural mindset facilitating males to better health care accessibility leading to higher diagnosis in them. ${ }^{10}$ Majority of patients in our study were in $5^{\text {th }}$ and $6^{\text {th }}$ decade of life (only one case presented at the age of 36). Commonest site involved in our study was hypopharynx - 96 cases, followed by larynx - 74 cases. Next commonest malignancy was oropharynx - 45 cases, followed by oesphagus - 38 cases, and oral cavity - 32 cases.

\section{CONCLUSION}

Out of the 312 cases of HNM seen in ENT OPD in our study only 153 were evaluated for surgery out of which 55 were considered fit for surgery but only 15 patients under went curative surgery. Out of the 15,8 were those with laryngeal and hypopharyngeal malignancy who underwent total Laryngectomy. Another 3 patients under went total maxillectomy for ca maxilla and one patient with oropharygeal ca (soft palate ca) underwent wide excision. The remaining three patients with ca of the face underwent wide excision. Despite having a large turnover of HNM patients only 15 patients were willing to undergo curative surgery. This less number could be due to unwillingness to accept deformity, patient's low economic status, lack of awareness amongst both patients and referring doctors, and lastly either due to advanced stage of disease or patient being medically unfit for surgery. However in our study 14 out of 15 patients who underwent curative surgery had more than 5 years survival rate with very few post-operative complications.

\section{Funding: No funding sources \\ Conflict of interest: None declared \\ Ethical approval: The study was approved by the institutional ethics committee}

\section{REFERENCES}

1. Bhurgri $\mathrm{Y}$, Hasan SH, Pervez S, Kayani N, Hussainy AS, Muzaffar S, et al. Large-scale pathology-based cancer data: a reflection of population based cancer data. Pathol Oncol Res. 2002;8:62-7.

2. Basu R, Mandal S, Ghosh A, Poddar TK. Role of Epidemiology and histopathological spectrum of head and neck cancers in Bihar, a state of Eastern India tobacco in the development of head and neck squamous cell carcinoma in an eastern Indian population. Asian Pac J Cancer Prev. 2008;9:381-6.

3. Ramnath Takiar, Deenu Nadayil, A. Nandakumar. Projections of number of cancer cases in India by cancer groups, (2010-2030). Asian Pac J Cancer Prev. 2010;11:1045-9.

4. Yeole BB. Epidemiologic trends of head neck cancers. Mumbai, India: Indian Cancer Society; 2001: 25-50. 
5. Sankaranarayanan R, Swaminathan R, Black RJ. Global variations in cancer survival. Cancer. 1996 Dec;78(12):2461-4.

6. Chaturvedi. Quality of life in head and neck cancer survivors: a cross-sectional survey. Am J Otolaryngol. 2009 May-Jun;30(3):176-80.

7. Vikram Kekatpure, M. Abraham Kuriakose. Oral cancer in India: learning from different populations. Cancer Prev. 2010;14:6.

8. Thapa N, Jha AK, Rijal JP, Shah A. Study on head and neck tumours presented in ENT OPD of Nepal Medical College teaching Hospital. Nepal Med Coll J. 2003;5:79-81.
9. Baskota DK, Agrawal R, Prasad R, Sinha BK. Distribution of malignancies in head and neck regions and their management. J Nep Med Assoc. 2005;44:68-72.

10. Sankaranarayanan R, Masuyer E, Swaminathan R, Ferlay J, Whelan S. Head and neck cancer: a global perspective on epidemiology and prognosis. Anticancer Res. 1998;18:4779-86.

Cite this article as: Shetty $\mathrm{H}$, Gangadhar KS. A clinical study of head and neck malignancy in a tertiary hospital. Int J Otorhinolaryngol Head Neck Surg 2015;1:69-74. 